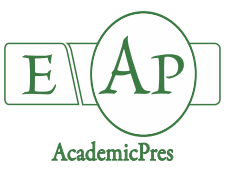

Dănăilă-Guidea SM et al. (2021)

Notulae Botanicae Horti Agrobotanici Cluj-Napoca

Volume 49, Issue 2, Article number 12330

DOI: $10.15835 /$ nbha 49212330

Research Article

\title{
Analysis of some physiological indicators in tomato plants to characterize the effects of additional lighting with blue, red and white LEDs
}

\author{
Silvana M. DĂNĂILĂ-GUIDEA ${ }^{1 *}$, Elena DELIAN ${ }^{2,3}$, \\ Paul-Alexandru POPESCU ${ }^{1}$, Mihaela-Cristina DRĂGHICI ${ }^{1}$, \\ Gabriela-Lucica MĂRGĂRIT ${ }^{1}$, Elisabeta E. POPA ${ }^{1}$, \\ Ioana-Cătălina NICOLAE²,3, Liliana BĂDULESCU ${ }^{2,3}$ \\ ${ }^{1}$ University of Agronomic Sciences and Veterinary Medicine of Bucharest, Faculty of Biotechnology, 59 Mărăsti Blvd, District 1, \\ Postal Code 011464,Bucharest, Romania; silvana.danaila@biotehnologii.usamv.ro (*corresponding author); \\ paul.alex.popescu@gmail.com; mihaeladraghici38@gmail.com;gabriela.margarit@biotehnologii.usamv.ro; \\ elena.eli.tanase@gmail.com \\ ${ }^{2}$ University of Agronomic Sciences and Veterinary Medicine of Bucharest, Faculty of Horticulture, 59 Mărăsti Blvd, District 1, Postal \\ Code011464,Bucharest,Romania; delianelena@yahoo.com; catalinaioana.nicolae@gmail.com; \\ liliana.badulescu@usamv.ro \\ ${ }^{3}$ Research Center for Studies of FoodQuality and Agricultural Products-Hortinvest, 59 Mărăşti Blvd, District 1, Bucharest, Romania
}

\begin{abstract}
The use of light-emitting diodes (LEDs) in vegetable species is one of the technological procedures applied to improve the spectral composition of light in protected areas, as well as to stimulate plant growth, obtaining high values of production and increasing resistance to conditions of culture. The biological material represented by tomato seedlings, from varieties with nutritional value and with high ecological plasticity, was studied in terms of characterizing the effects of applying the treatment using light fields emitted by blue, red and white LEDs, by analysis physiological parameters, such as: photosynthesis intensity $\left(\mu \mathrm{mols} \mathrm{CO}_{2} \mathrm{~m}^{-2} \mathrm{~s}^{-1}\right)$, transpiration intensity (mmoles $\left.\mathrm{H}_{2} \mathrm{O} \mathrm{m}^{-2} \mathrm{~s}^{-1}\right)$, stomatal conductance $\left(\right.$ mols $\left.\mathrm{H}_{2} \mathrm{O} \mathrm{m}^{-2} \mathrm{~s}^{-1}\right)$ and intercellular carbon dioxide $\left(\mu \mathrm{mol} \mathrm{CO} \mathrm{mol}^{-1}\right.$ air). In this study, the estimation of the amount of total chlorophyll $\left(\mathrm{mg} \mathrm{m}^{-2}\right)$, was also investigated. The determinations of the physiological parameters were performed in 3 series, and the recorded results were statistically analysed, by expressing the significance of the differences between the control and the studied tomato varieties being studied. Thus, after the treatment period, applied in 23 days (Series II), with monochrome LEDs, at the level of the stomatal conductance parameter, statistically assured values were registered for the plants in the 'L-75' line exposed to White LED and for those in the 'L-76' line exposed to the Blue LED. The analysis of the results from the investigation of the physiological parameters at the level of the leaves from the experimental samples indicated that after 35 days (Series III), from the application of the treatments of 30 minutes/day, with White LED light, they ensured the plants tomatoes from the 'L-76' line, distinctly significantly positive values, compared to those of the control plants, at the intensity of photosynthesis and the internal concentration of $\mathrm{CO}_{2}$.
\end{abstract}

Keywords: light solutions; LEDs; tomato; physiological parameters

Received: 31 Mar 2021. Received in revised form: 04 May 2020. Accepted: 06 May 2021. Published online: 13 May 2021.

From Volume 49, Issue 1, 2021, Notulae Botanicae Horti Agrobotanici Cluj-Napoca journal uses article numbers in place of the traditional method of continuous pagination through the volume. The journal will continue to appear quarterly, as before, with four annual numbers. 


\section{Introduction}

Due to their global importance (Hoza, 2003; Kimura and Sinha, 2008), tomatoes have been breeding over time to improve their productivity, fruit quality and resistance to biotic and abiotic stressors (Raiola et al., 2014; Glăman et al., 2015). The use of genetically resistant varieties and hybrids is a sustainable long-term management solution for disease and pest populations. There are 13 recognized species of wild tomatoes (such as $S$. chimielewskii, S. habrochaines, S. penellii, S. pimpinellifolium), all diploid $(2 \mathrm{n}=24)$, which have a wide variety of phenotypes and can be used in crosses with cultivated varieties (Peralta and Spooner, 2000; Indrea et al., 2007; Kimura and Sinha, 2008; Lagunovschi-Luchian and Vînătoru, 2016).

The use of genetically resistant varieties and hybrids is an important element of integrated management that leads to increased sustainability, reduced pesticide and fuel inputs, increased quantity and quality of production, without affecting biodiversity too much (Stevens and Rick, 1986; Burnichi et al., 2020).

On December 15, 2020, in an official statement, QU Dongyu, the General Director of Food and Agriculture Organization of the United Nations (FAO), designated the calendar year 2021 as the "International Year of Fruit and Vegetables" - IYFV (http://www.fao.org/news/story/en/item/1364762/ icode $)$. This international event took place through virtual platforms (online) and called for improving the production of healthy and sustainable food through innovation and technology and to reduce food loss and waste. Proclaimed at the 74th session of the UN General Assembly, IYFV 2021, it was dedicated to raising awareness of the important role of fruits and vegetables in human nutrition, food security and health.

Among the factors influencing plant growth, light is considered essential in performing photosynthesis itself (Kaiser et al., 2018; Zhang et al., 2019), and the amount, composition and duration of its action affect many other physiological processes (Taiz and Zigler, 2010), both in the case of protected and outdoor cultivated plants (Asănică et al., 2017).

Although other species of Solanaceaesuch as Capsicum annum (Bradley and Janes, 1985; Dorais, 1995), can be grown in a long ( 20 hours) or continuous photoperiod, without adverse effects on plant productivity, in case of tomatoes, productivity begins to decrease as the number of light hours increases (Vezina et al., 1991; Zamfir et al., 2020). Pepper plants can adapt to photoperiods longer than 20 hours, by increasing the carboxylation capacity and by increasing the amount of synthesized carotenoids and xanthophylls (Dorais, 1995; Demers and Gosselin, 2002). With the increase in lighting duration from 12 to 24 hours, the process of $\mathrm{CO}_{2}$ assimilation has significantly increased (Dorais, 1995).

Regarding tomatoes, studies have shown that at photoperiods of 20-24 hours, plants develop chlorosis on young leaves (Vezina et al., 1991). Studies conducted by Lanoue et al. (2019), showed that the reaction of tomato and cucumber plants to long photoperiods also depends on the spectrum of light to which they are subjected. They have shown that alternating red light and blue light during a continuous photoperiod can reduce the adverse effects of continuous lighting. The parameters related to photosynthetic activity were similar between plants grown at a photoperiod of 12 hours and plants grown at a continuous photoperiod and with alternating red and blue light. The combination of the two color lights stimulates biomass (Lefsrud et al., 2008) and fruit production by up to $20 \%$ compared to a single color (Brazaityte et al., 2009; Gotto et al., 2013).

In the research conducted by Podgoreanu et al. (2015), to determine the difference in response of 7 genotypes of Camelina sativa L., to LED lightning, optimal cultivation conditions were ensured by adding panels with specific LEDs arranged in red and blue strips within the greenhouse compartment used for experiments. In three of the evaluated genotypes (new hybrid line 'FP-5-02', 'Camelia' and 'Calena') higher values were recorded by which the calculated average was exceeded, in terms of seed yield, as well as the total weight of seeds/plant (g), average seed/pod and weight of 1000 seeds/plant (g).

In addition to the stimulating effect, it has on the growth and development processes, blue light stimulates the resistance of plants to biotic stressors. Kim et al. (2013) demonstrated that the use of blue LED 
light lamps in tomatoes grown in the greenhouse increases resistance to Botrytis cinerea, a mechanism that may be due to proline accumulation. Compared to plants illuminated with white LED light, plants illuminated with blue light had a 296\% higher proline content in leaves and $127 \%$ higher in shoots. Also, compared with white LED light, the accumulation of proline was lower in the case of lighting with red or green LED light. The total content of phenolic compounds was higher in the case of lighting with blue light, compared with white, red and green. In addition, within the studies approached by Dhakal and Baek (2014), it was shown that lighting with blue LED light 7 days before harvest can increase the shelf life of tomato fruits by delaying post-harvest ripening.

The purpose of these experiments was to test the effects produced by light emitting diodes (LEDs) in monochrome colors, characterized by a narrow spectrum of light, in a greenhouse compartment for growing tomato plants. The aim was to focus light with necessary wavelength for plant growth and to establish the factors that can favor the improvement of the management of agrosystems with non-polluting technological links.

\section{Materials and Methods}

The experiments were conducted over a period of three months (October-December 2019), in one of the compartments located in the "Greenhouse-block of automated research", within the infrastructure of the Research Center for the Study of Agri-Food Quality-Hortinvest, University of Agronomic Sciences and Veterinary Medicine Bucharest, Romania (http://erris.gov.ro/RESEARCH-CENTER-FOR-STUDIES-1).

\section{Biological materials}

Seeds from 3 varieties of tomatoes were used, represented by lines (line 'L-75', line 'L-76', and line 'L1.03 ') under study at the time of supply by Vegetable Research and Development Station (V.R.D.S.) Buzău, Romania, for approval by the national authorities. Their sowing was performed, starting with the first decade of September 2019, in alveolar trays. The first seedlings were observed 7-8 days after sowing. About 30 days after sowing the seeds, the seedlings of the 3 varieties of tomatoes studied developed 2-3 layers of leaves at the level of elongated stems. At this stage, the seedlings were transplanted in pots having $11 \mathrm{~cm}$ height and the sides of $10 \mathrm{~cm}$ in which $500 \mathrm{ml}$ substrate/pot was added (Figure 1).
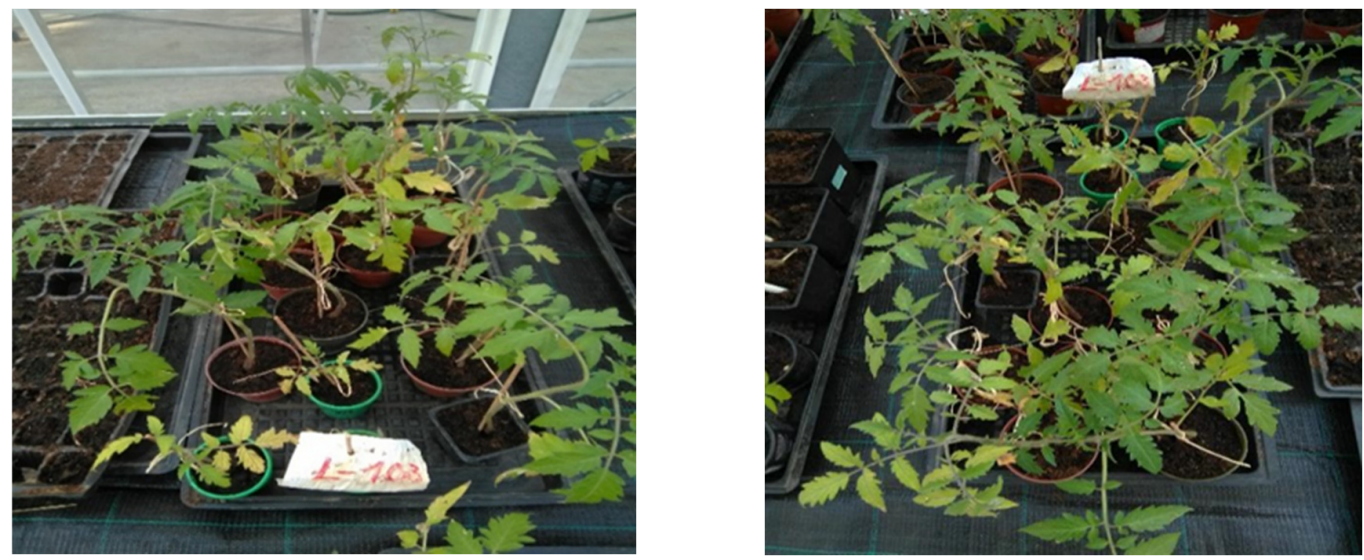

Figure 1. Appearance of tomato seedlings in the 'L-1.03' line developed after 30 days from sowing (Greenhouse-block of automated research - UASVM Bucharest; Authors photo, the third decade of October 2019)

The second transplantation was performed at 45 days from sowing, in square pots with side dimensions of $15 \mathrm{~cm}$ (750 ml substrate/pot). For the transplanting stages the substrate used was KEKILLA Professional 
type peat, pre-fertilized with macroelements, such as nitrogen $(\mathrm{N})$, phosphorus $(\mathrm{P})$, potasium $(\mathrm{K})$ in a ratio of $15-5-24 \mathrm{~kg} \mathrm{~m}^{-3}$ and natural calcium carbonate (СаCO3). The $\mathrm{pH}$ value was around 5.9. Specific care works were applied to the seedlings namely: watering, removal of yellowing leaves, tying the plants to tutors and facial at intervals of 7 days, as well as foliar fertilization treatments with universal organic fertilizer, based on biohumus extract (Lumbreco Romania).

The development of seedlings in all 3 varieties of tomatoes, took place without the registration of attacks of diseases and pests that affect their growth.

In November and December 2019, due to poor lighting conditions and to increased fog, the light was supplemented after the application of LED treatments and additional lighting during the day, using 4 halogen neons arranged at a height of $4 \mathrm{~m}$ above.

\section{Experimental procedures}

A three-factor experimental scheme was drawn up, as follows: Factor A - 3 lines of Romanian tomatoes ('L-75', 'L-76', 'L-1.03'); Factor B - light emitted by the LEDs arranged on panels in 3 graduations (Red, Blue, White), compared to the Control maintained only in natural light (for 9-10 hours/day) and Factor C - 30 minutes of additional LED lighting treatments. follows:

There were performed 3 series of determinations (symbolized by Series I, Series II and Series III) as

-Series I before applying the additional lighting treatment with monochrome LEDs (seedlings aged 55 days);

-Series II after 23 days of application of the additional lighting treatment with high power LEDs with monochrome light (White, Red and Blue) with a duration of 30 minutes/day for seedlings aged 78 days;

- Series III, after 35 days from the application of the additional lighting treatment with high-power LEDs with monochrome light (White, Red and Blue) lasting 30 minutes/day, at seedlings aged 90 days.

During 35 days, the tomato plants subjected to lightning treatments were monitored daily. In parallel, seedlings from each variety of tomatoes ('L-75', 'L-76', 'L-1.03'), from the experimental variants (Sample and Control), were provided in 3 repetitions.

LEDs are an alternative to artificial lighting in greenhouses with many advantages. They are light emitting devices based on semiconductors. In this study, 3 LED panels, model VEGETA, developed by the company S.C. Electromagnetica S.A., Bucharest, Romania (https://www.electromagnetica.ro/en/led-lightingsolution/), at the dimensions of: $385 \mathrm{~mm} \times 264 \mathrm{~mm} \times 169 \mathrm{~mm}$, which provided an intensity of 10,000 lx. to the Blue LEDs and the Red LEDs, and of at least $7900 \mathrm{~lm}$ respectively, for the luminous flux of the LEDs in neutral White.

\section{Physiological parameters}

At the level of the third leaf at the apex of the main stem of tomato seedlings, determination of physiological parameters was performed at the light intensity existing in the greenhouse (about $200 \mu \mathrm{mols} \mathrm{m}$ $\left.{ }^{2} \mathrm{~s}^{-1}\right)$, by means of specific measurements.

The physiological parameters, such as: photosynthesis intensity $\left(\mu \mathrm{mols} \mathrm{CO}_{2} \mathrm{~m}^{-2} \mathrm{~s}^{-1}\right)$, transpiration intensity (mmoles $\mathrm{H}_{2} \mathrm{O} \mathrm{m}^{-2} \mathrm{~s}^{-1}$ ), stomatal conductance $\left(\right.$ mols $\mathrm{H}_{2} \mathrm{O} \mathrm{m}^{-2} \mathrm{~s}^{-1}$ ) and intercellular carbon dioxide ( $\mu \mathrm{mol} \mathrm{CO} \mathrm{Col}^{-1}$ air), were determined using the portable analyzer LCpro-SD ADC BioScientific for measuring photosynthesis, equipped with an infrared gas analyzer, between hours 9:00 AM- 11:00 AM.

Simultaneously, the amount of total chlorophyll $\left(\mathrm{mg} \mathrm{m}^{-2}\right)$ was estimated by the non-destructive method, using the CCM-300 Opti Sciences chlorophyll meter. 


\section{Statistical analysis}

The results recorded by determining the physiological parameters in tomato plants were statistically analysed, before and after the application of the treatment with monochrome light emitted by LEDs, from the experimental scheme developed. For the statistical interpretation, the obtained data was analysed and calculated using Microsoft Excel software. The statistical analysis referred to the significance of the differences between the control and the tomato varieties studied, for each of the experimental series analysed under protected conditions.

The experiment was performed in a completely randomized block design. Data were analysed by unidirectional analysis of variance (ANOVA) and T-Test $(\mathrm{P}<0.05)$.

\section{Results and Discussion}

\section{Experimental results recorded for physiological indicators}

The results obtained for Series I, on the tomato leaves not previously exposed to LED light treatments are shown in Table 1. For the statistical analysis of the values for the physicological indicators determined on each plant of the three varieties, the $T$ test was applied and the evaluation of the results was obtained for each column, taking as a benchmark the highest value recorded.

The photosynthesis rate was close between the tomato line ' $\mathrm{L}-75$ ' and ' $\mathrm{L}-1.03$ ', the values being lower compared to the values of ' $\mathrm{L}-76$ ', which were significantly higher $12.20\left(\mu\right.$ moles $\left.\mathrm{CO}_{2} \mathrm{~m}^{-2} \mathrm{~s}^{-1}\right)$.

Table 1. The values of some physiological indicators registered on the leaves of tomato plants (Series I (mean \pm SE; $\mathrm{n}=3$ )

\begin{tabular}{|l|c|c|c|c|}
\hline \multirow{2}{*}{$\begin{array}{c}\text { Tomato } \\
\text { line }\end{array}$} & $\begin{array}{c}\text { Net photosynthesis } \\
\text { rate } \\
\left(\mu \text { moles } \mathrm{CO}_{2} \mathrm{~m}^{-2} \mathrm{~s}^{-1}\right)\end{array}$ & $\begin{array}{c}\text { Transpiration } \\
\text { rate } \\
\left(\mathrm{mmoles}_{2} \mathrm{O} \mathrm{m}^{-2} \mathrm{~s}^{-1}\right)\end{array}$ & $\begin{array}{c}\text { Determinations performed } \\
\begin{array}{c}\text { Sonductal } \\
\left(\mathrm{mols}_{2} \mathrm{O} \mathrm{m}^{-2} \mathrm{~s}^{-1}\right)\end{array}\end{array}$ & $\begin{array}{c}\text { Internal } \mathrm{CO}_{2} \\
\text { concentration } \\
\left(\mu \mathrm{mol} \mathrm{CO}_{2} \mathrm{~mol}^{-1}\right)\end{array}$ \\
\hline 'L-75' & $7.50 \pm 1.41^{\mathrm{ns}}$ & $4.51 \pm 0.13^{\mathrm{ns}}$ & $0.32 \pm 0.04^{\mathrm{ns}}$ & $351.80 \pm 13.07$ \\
\hline 'L-76' & $12.20 \pm 3.15$ & $5.87 \pm 0.72$ & $0.47 \pm 0.12$ & $339.73 \pm 28.08^{\mathrm{ns}}$ \\
\hline 'L-1.03' & $7.23 \pm 1.42^{\mathrm{ns}}$ & $3.68 \pm 0.51^{0}$ & $0.35 \pm 0.12^{\mathrm{ns}}$ & $343.20 \pm 33.08^{\mathrm{ns}}$ \\
\hline
\end{tabular}

Note: The Significance of differences from the maximum value recorded (by the respective varieties and determination data) (xxx, 000 - P <0.001; xx, 00 - P <0.01; x, 0- P <0.05; ns - nonsignificant)

Significantly higher values of the transpiration rate were determined for the 'L-76' tomato line, compared to those of the 'L-1.03' and 'L-75' lines, which indicates a relationship with the high photosynthetic rate, specified above. Also, the stomatal conductance value was higher for ' $\mathrm{L}-76$ ' $\left(0.47 \mathrm{mols}_{2} \mathrm{O} \mathrm{m}^{-2} \mathrm{~s}^{-1}\right)$ being a positive link with transpiration rate and photosynthesis intensity. As regard to the internal $\mathrm{CO}_{2}$ concentration, the results obtained are different as compared to those mentioned in stomatal conductance, respectively, the higher value was recorded at 'L-75', but this value was not significantly compared to the other two obtained values.

It is estimated that the improvement of cultivation technology in protected areas by using more efficient and environmentally friendly lighting systems is important (Van Straten et al., 2010), because light has a major limitation on vegetative growth but also due to high requirements related to light to obtain a high production, especially in temperate areas, where the days are short and an increased cloudiness is observed during seedling production (Gherghi et al., 2001; Burzo et al., 2004; Delian, 2008).

The results obtained at 23 days after the application of the LEDs light treatments (Series II) are presented in Table 2 (A-D). 
The values obtained for of ' $\mathrm{L}-75$ ' line and 'L-76' line tomato plants regarding the photosynthesis rate were not significantly different compared to the Control, while very significant lower values $\left(3.41 \mu\right.$ moles $\mathrm{CO}_{2}$ $\left.\mathrm{m}^{-2} \mathrm{~s}^{-1}\right)$ were recorded for plants belonging to ' $\mathrm{L}-1.03$ ' line suplimentary illuminated with White LED.

The transpiration rate, for ' $L-75$ ' line treated with White LED, presented values significantly lower compared to the Control, and for ' $\mathrm{L}-1.03$ ' very significant lower values were registered when treated with Blue LED ( $1.42 \mathrm{vs.} 2.58 \mathrm{mmol} \mathrm{H}_{2} \mathrm{O} \mathrm{m}^{-2} \mathrm{~s}^{-1}$ ). Regarding ' $\mathrm{L}-76$ ' line (Blue LED), the transpiration rate was significantly higher as compared to the Control (2.89 vs. $1.61 \mathrm{mmol} \mathrm{H}_{2} \mathrm{O} \mathrm{m}^{-2} \mathrm{~s}^{-1}$ ).

Table 2. The values of some physiological indicators registered on the leaves of tomato plants, compared to the untreated control - Series II (mean \pm SE; $n=3$ )

\begin{tabular}{|c|c|c|c|c|}
\hline \multirow{2}{*}{ Tomato line } & \multicolumn{4}{|c|}{ Experimental variant } \\
\hline & White LED & Blue LED & Red LED & Control \\
\hline \multicolumn{5}{|c|}{ A.) Net photosynthesis rate $\left(\mu\right.$ moles $\left.\mathrm{CO}_{2} \mathrm{~m}^{-2} \mathrm{~s}^{-1}\right)$} \\
\hline 'L-75' & $6.09 \pm 0.94^{\mathrm{ns}}$ & $6.62 \pm 0.76^{\mathrm{ns}}$ & $7.23 \pm 0.55^{\mathrm{ns}}$ & $7.80 \pm 0.29$ \\
\hline 'L-76' & $6.32 \pm 0.75^{\mathrm{ns}}$ & $7.10 \pm 1.57^{\mathrm{ns}}$ & $5.39 \pm 1.40^{\mathrm{ns}}$ & $4.83 \pm 0.99$ \\
\hline 'L-1.03' & $3.41 \pm 0.37^{00}$ & $5.30 \pm 0.76^{\mathrm{ns}}$ & $4.73 \pm 1.07^{\mathrm{ns}}$ & $5.00 \pm 0.31$ \\
\hline \multicolumn{5}{|c|}{ B.) Transpiration rate $\left(\right.$ mols $\left.\mathrm{H}_{2} \mathrm{O} \mathrm{m}^{-2} \mathrm{~s}^{-1}\right)$} \\
\hline 'L-75' & $1.57 \pm 0.23^{0}$ & $2.50 \pm 0.30^{\mathrm{ns}}$ & $3.00 \pm 0.66^{\mathrm{ns}}$ & $3.26 \pm 0.44$ \\
\hline 'L-76' & $1.72 \pm 0.49^{\mathrm{ns}}$ & $2.89 \pm 0.53^{x}$ & $2.20 \pm 0.42^{\mathrm{ns}}$ & $1.61 \pm 0.16$ \\
\hline 'L-1.03' & $2.72 \pm 1.53^{\mathrm{ns}}$ & $1.42 \pm 0.15^{000}$ & $3.22 \pm 1.33^{\mathrm{ns}}$ & $2.58 \pm 0.04$ \\
\hline \multicolumn{5}{|c|}{ C.) Stomatal conductance ( $\left.\mathrm{mols} \mathrm{H}_{2} \mathrm{O} \mathrm{m}^{-2} \mathrm{~s}^{-1}\right)$} \\
\hline 'L-75' & $0.17 \pm 0.02^{\mathrm{ns}}$ & $0.13 \pm 0.02^{\mathrm{ns}}$ & $0.14 \pm 0.04^{\mathrm{ns}}$ & $0.13 \pm 0.03$ \\
\hline 'L-76' & $0.12 \pm 0.04^{\mathrm{ns}}$ & $0.15 \pm 0.04^{x}$ & $0.08 \pm 0.02^{\mathrm{ns}}$ & $0.05 \pm 0.01$ \\
\hline 'L-1.03' & $0.07 \pm 0.02^{\mathrm{ns}}$ & $0.05 \pm 0.00^{00}$ & $0.07 \pm 0.01^{\mathrm{ns}}$ & $0.10 \pm 0.00$ \\
\hline \multicolumn{5}{|c|}{ D.) Internal $\mathrm{CO}_{2}$ concentration $\left(\mu \mathrm{mol} \mathrm{CO} \mathrm{mol}^{-1}\right)$} \\
\hline 'L-75' & $527.13 \pm 23.67 \times x$ & $544.07 \pm 36.21^{x}$ & $488.10 \pm 32.27^{\mathrm{ns}}$ & $430.80 \pm 18.91$ \\
\hline 'L-76' & $465.40 \pm 11.42^{x}$ & $540.47 \pm 2.11^{\mathrm{xx}}$ & $446.67 \pm 10.47^{x}$ & $401.30 \pm 16.80$ \\
\hline 'L-1.03' & $490.67 \pm 15.48^{x}$ & $453.27 \pm 22.12^{\mathrm{ns}}$ & $459.07 \pm 22.88^{\mathrm{ns}}$ & $427.73 \pm 15.63$ \\
\hline
\end{tabular}

Note: The Significance of differences from control is disclosed (by the respective plant varieties and determination data) $(x \mathrm{x}, 000-\mathrm{p}<0.001 ; \mathrm{xx}, 00-\mathrm{p}<0.01 ; \mathrm{x}, 0-\mathrm{p}<0.05 ; \mathrm{ns}-$ nonsignificant $)$

Stomatal conductance values were significantly higher for ' $\mathrm{L}-76$ ' line $\left(0.15 \mathrm{mols} \mathrm{H}_{2} \mathrm{O} \mathrm{m}^{-2} \mathrm{~s}^{-1}\right)$, illuminated with Blue LED, and the lowest value of $0.05 \mathrm{mols} \mathrm{H}_{2} \mathrm{O} \mathrm{m}^{-2} \mathrm{~s}^{-1}$, was registered for ' $\mathrm{L}-1.03$ ' line, also experimentally treated with Blue LED light.

Regarding the internal $\mathrm{CO}_{2}$ concentration parameter, the results obtained indicated distinctly significant positive values $(\mathrm{xx})$ recorded for the plants belonging to ' $\mathrm{L}-75$ ' line $\left(527.13 \mu \mathrm{mol} \mathrm{CO}_{2} \mathrm{~mol}^{-1}\right) / \mathrm{White}$ LED as well as in those belonging to ' $\mathrm{L}-76$ ' line $\left(540.47 \mu \mathrm{mol} \mathrm{CO}_{2} \mathrm{~mol}^{-1}\right) /$ Blue LED lighting, followed in descending order by the significantly positive values $(\mathrm{x})$ recorded by the plants treated with Blue LED, White LED and Red LED, compared to the minimum value of the Control plants in the ' $\mathrm{L}-76$ ' line $\left(401.3 \mu \mathrm{mol} \mathrm{CO}_{2}\right.$ $\left.\mathrm{mol}^{-1}\right)$.

In other research, such as the study conducted by Kaiser et al. (2019), on the influence of spectrum light supplementation on tomato plants, it was also observed that blue and red light had significant effects on biomass and photosynthesis. An additional 6\%-12\% of blue light was enough to achieve high productivity. However, 24\% supplementation of blue light was harmful to growth.

Menard et al. (2006) determined that supplementation with blue light can increase the rate of photosynthesis by up to $24 \%-30 \%$, depending on the species. Thus, they demonstrated that supplementation with Blue LED light in tomatoes and cucumbers grown in the greenhouse and illuminated with high pressure 
sodium (HPS) lamps increased productivity in both species. The best results were obtained by supplementing $16 \mu \mathrm{mol} \mathrm{m}^{-2} \mathrm{~s}^{-1}$ blue light at a photoperiod of 12 hours (Menard et al., 2006).

In Table 3 (A-D) are presented the results obtained for the third series (Series III) of determinations performed after 35 days of treatment application.

Regarding the photosynthesis rate, the highest value was recorded for the Control plants from the ' $\mathrm{L}$ 1.03' tomato line $\left(8.27 \mu\right.$ mols $\left.\mathrm{CO}_{2} \mathrm{~m}^{-2} \mathrm{~s}^{-1}\right)$. Tomato plants of the ' $\mathrm{L}-76$ ' line treated with White LED 30 minutes/day for 35 days, had distinctly significant positive values $(\mathrm{xx})$, when determining the intensity rate of photosynthesis $\left(7.55 \mu \mathrm{mol} \mathrm{CO}_{2} \mathrm{~m}^{-2} \mathrm{~s}^{-1}\right)$, compared to the lowest value of $5.09 \mu \mathrm{mols}_{\mathrm{C}} \mathrm{CO}_{2} \mathrm{~m}^{-2} \mathrm{~s}^{-1}$, also determined for plants from L-76, but illuminated with Blue LEDs.

Table 3. The values of some physiological indicators registered on the leaves of tomato plants, compared to the untreated control - Series III (mean \pm SE; $n=3$ )

\begin{tabular}{|c|c|c|c|c|}
\hline \multirow{2}{*}{$\begin{array}{c}\text { Tomato } \\
\text { line }\end{array}$} & \multicolumn{4}{|c|}{ Experimental variant } \\
\hline & White LED & Blue LED & Red LED & Control \\
\hline \multicolumn{5}{|c|}{ A.) Net photosynthesis rate $\left(\mu\right.$ moles $\left.\mathrm{CO}_{2} \mathrm{~m}^{-2} \mathrm{~s}^{-1}\right)$} \\
\hline 'L-75' & $6.39 \pm 0.45^{\mathrm{ns}}$ & $6.91 \pm 0.82 \mathrm{~ns}$ & $7.76 \pm 1.23^{\mathrm{ns}}$ & $6.18 \pm 0.52$ \\
\hline 'L-76’ & $7.55 \pm 0.21^{\mathrm{xx}}$ & $5.09 \pm 0.23^{00}$ & $4.76 \pm 1.39^{\mathrm{ns}}$ & $6.57 \pm 0.14$ \\
\hline 'L-1.03' & $5.73 \pm 0.56^{0}$ & $5.86 \pm 0.68^{0}$ & $6.40 \pm 0.40^{\mathrm{ns}}$ & $8.27 \pm 1.06$ \\
\hline \multicolumn{5}{|c|}{ B.) Transpiration rate $\left(\right.$ mmoles $\left.\mathrm{H}_{2} \mathrm{O} \mathrm{m}^{-2} \mathrm{~s}^{-1}\right)$} \\
\hline 'L-75' & $1.04 \pm 0.13^{0}$ & $1.98 \pm 0.17^{\mathrm{ns}}$ & $1.98 \pm 0.24^{\mathrm{ns}}$ & $2.57 \pm 0.42$ \\
\hline 'L-76' & $1.80 \pm 0.15^{\text {ns }}$ & $1.22 \pm 0.06^{0}$ & $1.44 \pm 0.21^{0}$ & $1.67 \pm 0.12$ \\
\hline 'L-1.03' & $1.12 \pm 0.11^{0}$ & $1.32 \pm 0.15^{00}$ & $1.85 \pm 0.21^{\mathrm{ns}}$ & $1.97 \pm 0.23$ \\
\hline \multicolumn{5}{|c|}{ C.) Stomatal conductance $\left(\right.$ mols $\left.\mathrm{H}_{2} \mathrm{O} \mathrm{m}^{-2} \mathrm{~s}^{-1}\right)$} \\
\hline 'L-75' & $0.08 \pm 0.01^{\mathrm{ns}}$ & $0.09 \pm 0.01^{\mathrm{ns}}$ & $0.07 \pm 0.01^{\mathrm{ns}}$ & $0.10 \pm 0.02$ \\
\hline 'L-76' & $0.08 \pm 0.00^{\mathrm{xx}}$ & $0.04 \pm 0.00^{0}$ & $0.05 \pm 0.01^{\mathrm{ns}}$ & $0.06 \pm 0.00$ \\
\hline 'L-1.03' & $0.05 \pm 0.01^{\mathrm{ns}}$ & $0.04 \pm 0.00^{\mathrm{ns}}$ & $0.04 \pm 0.00^{\mathrm{ns}}$ & $0.07 \pm 0.01$ \\
\hline \multicolumn{5}{|c|}{ D.) Internal $\mathrm{CO}_{2}$ concentration $\left(\mu \mathrm{mol} \mathrm{CO} \mathrm{Col}^{-1}\right)$} \\
\hline 'L-75' & $432.40 \pm 15.09^{0}$ & $456.13 \pm 9.80^{\text {ns }}$ & $402.67 \pm 18.58^{0}$ & $497.67 \pm 24.51$ \\
\hline 'L-76' & $456.37 \pm 13.67^{\mathrm{ns}}$ & $411.60 \pm 9.70^{\text {ns }}$ & $458.10 \pm 10.19^{x}$ & $418.20 \pm 11.55$ \\
\hline 'L-1.03' & $413.33 \pm 5.46^{\mathrm{ns}}$ & $380.60 \pm 8.90^{\mathrm{ns}}$ & $436.87 \pm 20.25^{\mathrm{ns}}$ & $397.53 \pm 5.16$ \\
\hline
\end{tabular}

In the case of the transpiration intensity indicator, significantly higher values were recorded for the plants used as a Control in the tomato line ' $\mathrm{L}-75$ ' $\left(2.57 \mathrm{mmols}_{2} \mathrm{O} \mathrm{m}^{-2} \mathrm{~s}^{-1}\right)$, compared to the plants from the same line illuminated with White $\mathrm{LED}\left(1.04 \mathrm{mmols} \mathrm{H}_{2} \mathrm{O} \mathrm{m}^{-2} \mathrm{~s}^{-1}\right)$. For the plants of ' $\mathrm{L}-76$ ' line, decreasing values were registered following the treatments with White LED $<$ Red LED $<$ Blue LED $\left(1.22 \mathrm{mmols}_{2} \mathrm{O} \mathrm{m}^{-2} \mathrm{~s}^{-1}\right)$, compared to those in Control. In the case of plants of the ' $\mathrm{L}-1.03$ ' line, decreasing values were registered following the treatments with Red LED $<$ Blue LED $<$ White LED $\left(1.12 \mathrm{mmols}_{2} \mathrm{O} \mathrm{m}^{-2} \mathrm{~s}^{-1}\right)$.

For the physiological parameter of stomatal conductance, the highest value was recorded as well in the Control tomato plants from the ' $\mathrm{L}-75$ ' line $\left(0.10\right.$ mole $\left._{2} \mathrm{O} \mathrm{m}^{-2} \mathrm{~s}^{-1}\right)$. The lowest value of $0.04 \mathrm{~mole}_{2} \mathrm{O} \mathrm{m}^{-2} \mathrm{~s}$ ${ }^{1}$ was recorded in both 'L-1.03' plants treated with Blue LED and Red LED. In the 'L-76' line tomato plants additionally illuminated with White LED, the recorded value was distinctly significantly positive $(\mathrm{xx})$ compared to the Control.

In the case of internal $\mathrm{CO}_{2}$ concentration, for tomato ' $\mathrm{L}-76$ ' line plants illuminated with Red LED, the value of $458 \mu \mathrm{mol} \mathrm{CO}_{2} \mathrm{~mol}^{-1}$, was statistically calculated as a significant positive difference (x) from the Control plants. The highest value was recorded for the Control plants from the tomato line 'L-75' (497.67 $\mu \mathrm{mol} \mathrm{CO} 2$ $\left.\mathrm{mol}^{-1}\right)$. 
In Figure 2 are illustrates the tomato plants after this exposure interval to additional treatments with monochrome LED light (Red, Blue, and White) for $30 \mathrm{~min} /$ day.

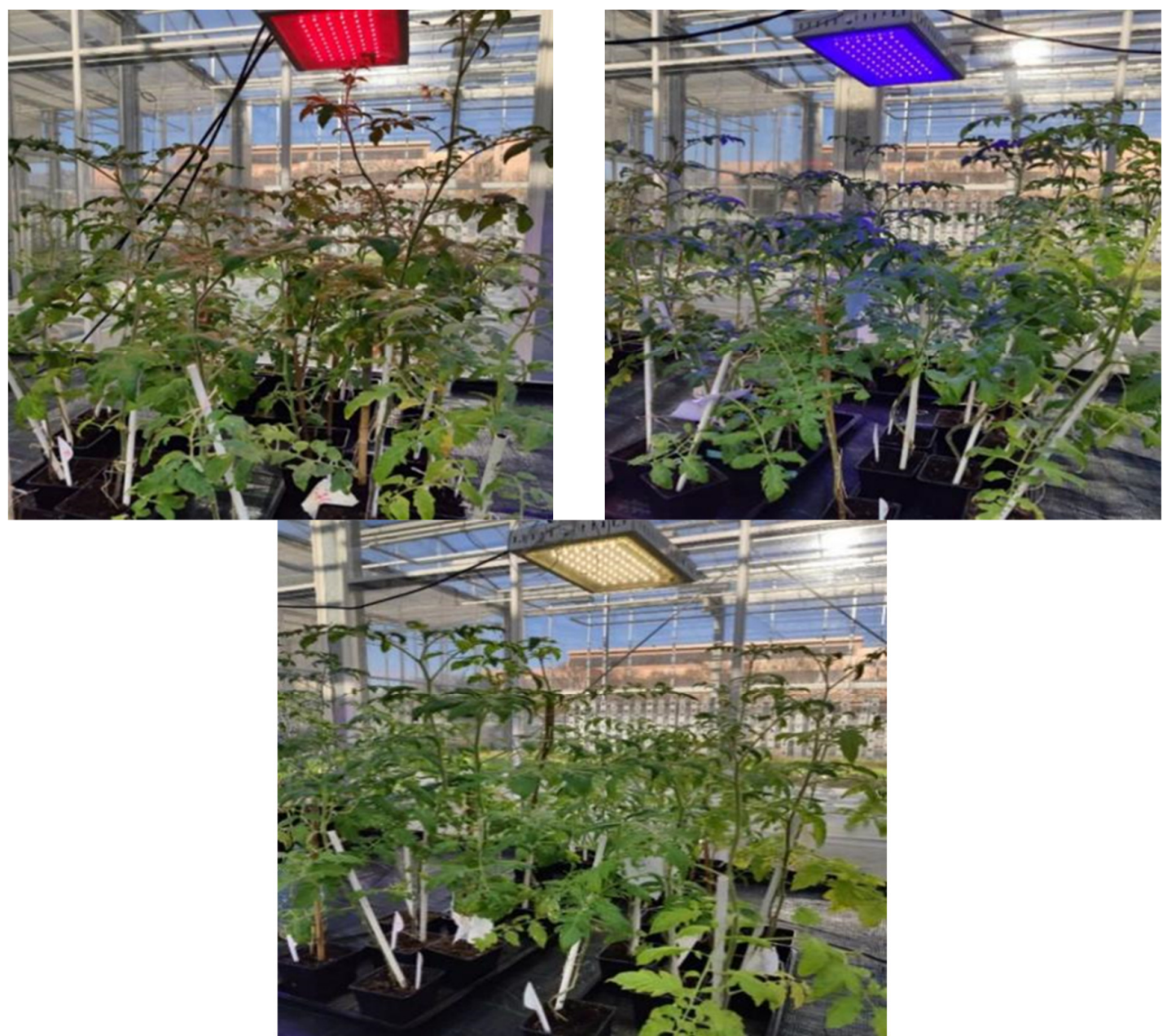

Figure 2. Aspects of the development of tomato plants after exposure for 35 days to LED-monochrome light

(Greenhouse-block of automated research - UASVM Bucharest; Authors photo, 09.12.2019)

The obtained results of Series III samples regarding the physiological indicators demonstrated that the tomato plants of the 3 varieties have reacted differently according to genotype to additional lighting treatments with monochrome White, Red and Blue LED light compared to untreated plants in the Control variant.

In one of our previous studies (Dănăilă-Guidea et al., 2020), it was found that there were no significant differences within the variants regarding the diameter of the stems measured at the base for the plants in the tomato line 'L-75', the average of the values recorded varying between $0.2 \mathrm{~cm}$ and $0.5 \mathrm{~cm}$, with statistically insignificant assurance (ns '-'). These results showed that the stem thickness in tomato plants was largely influenced by genotypic characters, and in may small amount by light color or duration of exposure of plants to artificial LED lighting.

However, in a study performed by Gomez and Michel (2015), it was shown that supplementing natural light with a combination of red and blue light, led to a better growth of tomato seedlings in terms of morphological parameters analyzed, namely hypocotyl diameter, epicotyl length, dry mass, number of leaves and leaf size. 


\section{Experimental results recorded for total chlorophyll}

Data on total chlorophyll estimation are given in Tables 4, 5 and 6. Results recorded before the LED treatment (Series I) on the third leaf at the apex of the main stem of the 55-day-old tomato seedlings, are shown in Table 4.

Table 4. Total chlorophyll content $\left(\mathrm{mg} \mathrm{m}^{-2}\right)$ of tomato leaves - Series I (mean \pm SE; $\left.\mathrm{n}=3\right)$

\begin{tabular}{|l|c|}
\hline \multicolumn{1}{|c|}{ Tomato line } & Recorded values \\
\hline 'L-75' & $617.80 \pm 0.69$ \\
\hline 'L-76' & $609.27 \pm 6.79^{\text {ns }}$ \\
\hline 'L-1.03' & $615.27 \pm 3.09^{\text {ns }}$ \\
\hline
\end{tabular}

Note: The significance of differences from the maximum value recorded (by the respective varieties and determination data);

$(\mathbf{x x}, 000-p<0.001 ; \mathbf{x x}, 00-p<0.01 ; \mathbf{x}, 0-p<0.05 ;$ ns - nonsignificant $)$

There were registered close values between $609.27\left(\mathrm{mg} \mathrm{m}^{-2}\right)$ for ' $\mathrm{L}-76$ ' line tomato plants and 617.80 $\left(\mathrm{mg} \mathrm{m}^{-2}\right)$ for the 'L-75' line. Results recorded for Series II samples are presented in Table 5.

Table 5. Total chlorophyll content $\left(\mathrm{mg} \mathrm{m}^{-2}\right)$ of tomato leaves- Series II (mean \pm SE; $\left.n=3\right)$

\begin{tabular}{|l|c|c|c|c|}
\hline \multirow{2}{*}{$\begin{array}{c}\text { Tomato } \\
\text { line }\end{array}$} & \multicolumn{4}{|c|}{ Experimental variant } \\
\cline { 2 - 5 } & White LED & Blue LED & Red LED & Control \\
\hline 'L-75' & $638.00 \pm 3.75^{\text {ns }}$ & $640.53 \pm 1.96^{\text {ns }}$ & $647.20 \pm 0.40^{\text {ns }}$ & $651.00 \pm 13.42$ \\
\hline 'L-76' & $641.33 \pm 2.48^{\text {ns }}$ & $650.47 \pm 11.67^{\text {ns }}$ & $650.87 \pm 1.88^{\text {ns }}$ & $645.27 \pm 4.79$ \\
\hline 'L-1.03' & $633.80 \pm 0.50^{\text {ns }}$ & $639.00 \pm 2.31^{\text {ns }}$ & $675.73 \pm 4.62^{\mathrm{x}}$ & $638.20 \pm 2.19$ \\
\hline
\end{tabular}

Note: Significance of differences from control is disclosed (by the respective plant varieties and determination data);

$(\mathbf{x x}, 000-\mathrm{p}<0.001 ; \mathbf{x x}, 00-\mathrm{p}<0.01 ; \mathbf{x}, 0-\mathrm{p}<0.05 ; \mathrm{ns}-$ nonsignificant $)$

For ' $\mathrm{L}-76$ ' tomato line the values higher than $650.87\left(\mathrm{mg} \mathrm{m}^{-2}\right)$ was found in the experimental samples illuminated with Red LED, being followed very closely at this value by the plants of the 'L-76' line illuminated with Blue LED, both higher compared to the value of the Control plants in the 'L-76' line. The lowest amounts were recorded for the plants of the 3 lines illuminated with White LED, the lowest in 'L-1.03' $\left(633.8 \mathrm{mg} \mathrm{m}^{-2}\right)$.

The results recorded at an interval of 35 days (Series III), compared to the first day of treatment with light emitted by the monochrome LEDs, at the level of the 3rd leaf at the apex of the main stem are shown in Table 6.

Table 6. Total chlorophyll content $\left(\mathrm{mg} \mathrm{m}^{-2}\right)$ of tomato leaves- Series III (mean \pm SE; $\mathrm{n}=3$ )

\begin{tabular}{|l|c|c|c|c|}
\hline \multirow{2}{*}{$\begin{array}{c}\text { Tomato } \\
\text { line }\end{array}$} & \multicolumn{4}{|c|}{ Experimental variant } \\
\cline { 2 - 5 } & White LED & Blue LED & Red LED & Control \\
\hline 'L-75' & $641.53 \pm 6.09^{\text {ns }}$ & $638.13 \pm 2.19^{\text {ns }}$ & $634.67 \pm 0.83^{\text {ns }}$ & $637.80 \pm 5.21$ \\
\hline 'L-76' & $635.60 \pm 0.69^{\text {ns }}$ & $635.30 \pm 6.64^{\text {ns }}$ & $629.80 \pm 2.65^{\text {ns }}$ & $633.70 \pm 4.56$ \\
\hline 'L-1.03' & $618.13 \pm 3.56^{00}$ & $617.86 \pm 6.37^{0}$ & $629.60 \pm 1.17^{00}$ & $640.90 \pm 0.40$ \\
\hline
\end{tabular}

Note: Significance of differences from control is disclosed (by the respective plant varieties and determination data);

$(\mathbf{x x}, 000-\mathrm{p}<0.001 ; \mathbf{x x}, 00-\mathrm{p}<0.01 ; \mathbf{x}, 0-\mathrm{p}<0.05 ; \mathrm{ns}-$ nonsignificant $)$

The highest value of total chlorophyll amount $\left(\mathrm{mg} \mathrm{m}^{-2}\right)$ determined for plants illuminated with White LED, was $641.5\left(\mathrm{mg} \mathrm{m}^{-2}\right)$ in ' $\mathrm{L}-75$ ' line, followed by values at $635.6\left(\mathrm{mg} \mathrm{m}^{-2}\right)$ for ' $\mathrm{L}-76$ ' line and 618.13 for ' $\mathrm{L}$ 1.03 '. The smallest quantities were registered in the plants belonging to ' $\mathrm{L}-1.03$ ' line in comparison with lines 'L-75' and 'L-76', under all colors of the LEDs light treatment. 
A study performed by Goto (2003), on the effect on plant growth under supplementing blue light in protected culture spaces, showed that it improves the growth of plant leaves.

Blue light also stimulates chlorophyll synthesis and stomatal opening, thus facilitating carbon dioxide absorption and photosynthesis, reducing shoot elongation and stimulating the synthesis of antioxidants.

Lefsrud et al. (2008), found that the ratio between blue and red light is one of the most important factors in terms of LED light influence on plant growth.

\section{Conclusions}

The effects of additional lighting treatments were different in relation to the genotype. For the plants belonging to ' $\mathrm{L}-76$ ' line, after 23 days from the application of the additional lighting treatment for 30 minutes/day with Blue LEDs, it was found that the physiological index of the internal $\mathrm{CO}_{2}$ concentration had distinctly significantly higher values, compared to the Control. Values of the stomatal conductance indicator were also significantly higher.

After 35 days of application of the additional light treatments emitted by White LEDs, very distinctly significant positive values were registered, regarding the net photosynthesis rate for the plants belonging to ' $\mathrm{L}$ 76 ' line, and also for transpiration rate and stomatal conductance indicator, respectively, compared to values recorded at the same parameter by the untreated Control plants.

However, the results of these studies, regarding the analysis of physiological indicators in tomato plants, reported less significant effects on the ' $L$-1.03' genotype, due to additional short-term illumination with White, Blue, and Red monochrome LEDs in the range of time analysed.

\section{Authors' Contributions}

Conceptualization: SMDG, ED and PAP; SMDG: Writing - original draft and project administration; ED: Conducted the statistical analysis and writing - review and editing; PAP and EEP: Data curation as well a preparation of manuscript according to journal rules, MCD and GLM: Formal analysis and funding acquisition; ICN: Partial contribution in writing - original draft; LB: Visualization and validation. All authors read and approved the final manuscript.

\section{Acknowledgements}

This work was supported by a grant of the Romanian Ministry of Research and Innovation,

CCCDIUEFISCDI, project number PN-III-P1-1.2-PCCDI-2017-0301/no. 28PCCDI/2018, within PNCDI III.

\section{Conflict of Interests}

The authors declare that there are no conflicts of interest related to this article. 


\section{References}

Asănică A, Delian E, Tudor V, Teodorescu RI (2017). Physiological activity of some blueberry varieties in protected and outside conditions. AgroLife Scientific Journal 6(1):31-39. http://agrolifejournal.usamv.ro/pdf/vol.VI_1/Art4.pd

Bradley FM and Janes HW (1985). Carbon partitioning in tomato leaves exposed to continuous light. Acta Horticulturae 174:293-302. https://doi.org/10.17660/ActaHortic.1985.174.37

Brazaitytė A, Duchovskis P, Urbonavičiūtè A, Samuolienė G, Jankauskienė J, Kazènas V, ... Žukauskas A (2009) Aftereffect of light-emitting diodes lighting on tomato growth and yield in greenhouse. Sodininkystè ir Daržininkystė 28(1):115-126.

Burnichi F, Strugariu CG, David M, Teodorescu EN, Petre C, Vlad C, Dănăilă-Guidea S, Călin M (2020). Interrelationships between agro-morphological parameters on organic tomato (Solanum lycopersicum L.). Acta Horticulturae 1297:245-254. https://doi.org/10.17660/ActaHortic.2020.1297.33

Burzo I, Delian E, Dobrescu A, Voican V, Bădulescu L (2004). Fiziologia plantelor de cultură. Vol. I. Procesele fiziologice din plantele de cultură. Ediție îmbunătățită [Romanian-Physiology of crop plants. Vol. I. Physiological processes in crop plants. Improved edition.]. Ceres Publishing House.Bucharest.

Dănăilă-Guidea SM, Neată G, Burnichi F, Popescu PA, Drăghici M, Vișan VL, ... Popa ME (2020). Cultivation technologies applied in the production of tomatoes plants for obtaining safe food products, under the conditions of climate change. "Life Sciences For Sustainable Development", International Conference 19th Edition, ClujNapoca, Book of Abstracts 7:226.

Delian E (2008). Fiziologia plantelor [Romanian-Plant physiology]. Printech Publishing House. Bucharest.

Demers DA, Gosselin A (2002). Growing greenhouse tomato and sweet pepper under supplemental lighting: Optimal photoperiod, negative effects of long photoperiod and their causes. Acta Horticulturae 580:83-88. https://doi.org/10.17660/ActaHortic.2002.580.9

Dhakal R, Baek KH (2014). Short period irradiation of single blue wavelights extends the storage period of mature green tomatoes. Postharvest biology and Technology 90:73-77. https://doi.org/10.1016/j.postharvbio.2013.12.007

Dorais M, Carpentier R, Yelle S, Gosselin A (1995). Adaptability of tomato and pepper leaves to changes in photoperiod: Effects on the composition and function of the thylakoid membrane. Physiologia Plantarum 94(4):692-700. https://doi.org/10.1111/j.1399-3054.1995.tb00986.x.

FAO (2021). FAO launches the UN's International Year of Fruits and Vegetables 2021. Retrieved 2021 January 12 from http://www.fao.org/news/story/en/item/1364762/icode/

Gherghi A, Burzo I, Bibicu M, Mărgineanu L, Bădulescu L (2001). Biochemistry and physiology of vegetables and fruits. Romanian Academy Publishing House, Bucharest, Romania (in Romanian).

Glăman G, Lăcătuş V, Scurtu I, Vînătoru C, Burnichi F, Heitz M, ... Cârstea LN (2015). Eating Romanian vegetables with Romanian taste. Supply with Romanian vegetable seeds in the period 2015-2020. Journal of Horticulture, Forestry and Biotechnology 19(1):166-175.

Gómez C, Mitchell CA (2015). Growth responses of tomato seedlings to different spectra of supplemental lighting. HortScience 50:112-118. https://doi.org/10.21273/HORTSCI.50.1.112

Goto E (2003). Effects of light quality on growth of crop plants under artificial lighting. Environmental Control in Biology 41:121-132. https://doi.org/10.2525/ecb1963.41.121

Goto R, de Miguel A, Ignacio Marsal J, Gorbe E, Calatayud A (2013). Effect of different rootstocks on growth, chlorophyll a fluorescence and mineral composition of two grafted scions of tomato. Journal of Plant Nutrition 36:825-835. https://doi.org/10.1080/01904167.2012.757321

Hoza G (2003). Sfaturi practice pentru cultura legumelor [Romanian-Practical advice for growing vegetables]. Nemira Publishing House. Bucharest.

Indrea D, Apahidean S, Apahidean M, Maniutiu DN, Sima R (2007). Cultura legumelor [Romanian-Vegetable cultivation]. Dumitru Indrea-coordinator. Ceres Publishing House. Bucharest.

Kaiser E, Matsubara S, Harbinson J, Heuvelink E, Marcelis LFM (2018). Acclimation of photosynthesis to lightflecks in tomato leaves: interaction with progressive shading in a growing canopy. Physiologia Plantarum 162(4):506517. https://doi.org/10.1111/ppl.12668

Kaiser E, Ouzounis T, Giday H, Schipper R, Heuvelink E, Marcelis LFM (2019). Adding blue to red supplemental light increases biomass and yield of greenhouse-grown tomatoes, but only to an optimum. Frontiers in Plant Science 9:e2002. https://doi.org/10.3389/fpls.2018.02002 
Kim K, Knook HS, Jang YJ, Lee WH, Kamala-Kannan S, Chae JC, Lee KJ (2013). The effect of blue-light-emitting diodes on antioxidant properties and resistance to Botrytis cinerea in tomato. Journal of Plant Pathology \& Microbiology 4:e1000203. https://doi.org/10.4172/2157-7471.1000203

Kimura S, Sinha N (2008). Tomato (Solanum lycopersicom): A model fruit bearing crop. Cold Spring Harbor Protocols, 3(11):1-9. https://doi.org/10.1101/pdb.emo105

Lagunovschi-Luchian V, Vînatoru C (2016). Legumicultura [Romanian-Vegetable growing]. Alpha MDN Publishing House. Buzău.

Lanoue J, Zheng J, Little C, Thibodeau A, Grodzinski B, Hao X (2019). Alternating red and blue light-emitting diodes allows for injury-free tomato production with continuous lighting. Frontiers in Plant Science 10:1114. https://www.frontiersin.org/article/10.3389/fpls.2019.01114

Lefsrud MG, Kopsell DA, Sams EC (2008). Irradiance from distinct wavelength light-emitting diodes affect secondary metabolites in kale. HortScience 43(7):2243-2244. https://doi.org/10.21273/HORTSCI.43.7.2243

Led-Lighting-Solution (2017). Electromagnetica S.A., Bucharest, Romania. Retrieved 2019 April 5 from https://www.electromagnetica.ro/en/led-lighting-solution/

Ménard C, Dorais M, Hovi T, Gosselin A (2006). Developmental and physiological responses of tomato and cucumber to additional blue light. Acta Horticulturae 711:291-296. https://doi.org/10.17660/ActaHortic.2006.711.39

Peralta IE, Spooner DM (2000). Classification of wild tomatoes: a review. Tomato 28(1):45-54.

Podgoreanu E, Jurcoane S, Dănăilă-Guidea SM, Roșu A, Săuca F, Moraru AC, Cristea S (2015). Studies on the effect of genotype on growth and seed yield in some Camelina sativa L varieties cultivated under controlled environmental conditions. AgroLife Scientific Journal 4(1):131-136. http://agrolifejournal.usamv.ro/pdf/vol.IV_1/Art19.pdf

Raiola A, Rigano MM, Calafiore R, Frusciante L, Barone A (2014). Enhancing the health-promoting effects of tomato fruit for biofortified food. Mediators of Inflammation 2014:1-16. https://doi.org/10.1155/2014/139873

Research Center for the Study of Agri-Food Quality, the University of Agronomic Sciences and Veterinary Medicine Bucharest [Centrul De Cercetare Pentru Studiul Calității Produselor Agroalimentare - HORTINVEST]. Retrieved 2021 March 15 from http://erris.gov.ro/RESEARCH-CENTER-FOR-STUDIES-1/

Stevens MA, Rick CM (1986). Genetics and breeding. In: Atherton JG and Rudich J (Eds). The Tomato Crop: A Scientific Basis for Improvement. Chapman and Hall, London pp 35-109.

Taiz L, Zeiger E (2010) Plant Physiology. Sinauer Associates Inc, Sunderland, Massachussetts, USA.

Van Straten G, Willigenburg G, Van Henten EJ, Ooteghem V (2010). Optimal control of greenhouse cultivation. CRC Press.

Vezina F, Trudel MJ, Gosselin A (1991). Influence du mode d'utilisation de l'éclairage d'appoint sur la productivité et la physiologie de la tomate de serre [French-Influence of various supplemental lighting treatments on the productivity and physiology of greenhouse tomato]. Canadian Journal of Plant Science 71:923-932. https://cdnsciencepub.com/doi/pdf/10.4141/cjps91-132

Zamfir B, Hoza D, Vînatoru C, Bratu C, Barcanu-Tudor E (2020). Yield and quality evaluation of processing tomatoes cultivars obtained in Romania. Acta Horticulturae 1292:37-44. https://doi.org/10.17660/ActaHortic.2020.1292.5

Zhang Y, Kaiser E, Zhang Y, Yang Q, Li T (2019). Red/blue light ratio strongly affects steady-state photosynthesis, but hardly affects photosynthetic induction in tomato (Solanum lycopersicum). Physiologia Plantarum 167(2):144158. https://doi.org/10.1111/ppl.12876
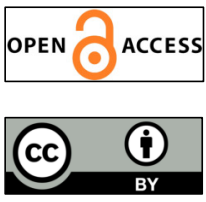

The journal offers free, immediate, and unrestricted access to peer-reviewed research and scholarly work. Users are allowed to read, download, copy, distribute, print, search, or link to the full texts of the articles, or use them for any other lawful purpose, without asking prior permission from the publisher or the author.

License - Articles published in Notulae Botanicae Horti Agrobotanici Cluj-Napoca are Open-Access, distributed under the terms and conditions of the Creative Commons Attribution (CC BY 4.0) License. (c) Articles by the authors; UASVM, Cluj-Napoca, Romania. The journal allows the author(s) to hold the copyright/to retain publishing rights without restriction. 